\title{
Innovation as a Vector of Regional Economic Development and a Necessary Condition for the Progress of the World Economy
}

\author{
Elena A. Yakovleva ${ }^{1}$, Natalia A. Azarova ${ }^{1} \&$ Elena V. Titova ${ }^{1}$ \\ ${ }^{1}$ Voronezh State Academy of Forestry and Technologies, Voronezh, The Russian Federation \\ Correspondence: Elena A. Yakovleva, Voronezh State Academy of Forestry and Technologies, 8 Timiryazeva St. \\ Voronezh, 394087, The Russian Federation. Tel: 79-10-346-8167. E-mail: elena-12-27@mail.ru
}

Received: January 20, 2015 Accepted: February 19, 2015 Online Published: June 13, 2015

doi:10.5539/ass.v11n20p90 URL: http://dx.doi.org/10.5539/ass.v11n20p90

\begin{abstract}
Innovative development is an essential component of economic development, responding to global challenges of our time. Please be aware that nowadays there is a great increase of not only the practical implementation of innovative technologies and processes, but also of theoretical understanding of these trends in theoretical studies. Exploring the nature of innovation processes and factors of their incentive economics focuses on the large-scale process of generating ideas and theories, issues of priority, issues of innovation, and economic and cultural backgrounds' need for innovative ideas. Innovation is the result of the transformation of ideas, research, development, new or improved scientific and technical, socio-economic, political and other decisions that promote, improve the quality and standards of living of the population and national security through the harmonization of the economic interests of economic entities (profit firms), market of consumer interests (needs at the lowest cost) and interests of society (rationalization needs, environmental protection, reduction of unemployment, the growth of the tax base, increase in average household incomes, reducing their differentiation, growth of intellectual potential of society, increase in life expectancy, increasing competitiveness of regions, countries and so on. Therefore, it is necessary to identify the role of innovation in the development of regional and global economy, which this study is dedicated to.
\end{abstract}

Keywords: economic development, innovation, progress, regional economy, world economy

\section{Introduction}

The last third of the $20^{\text {th }}$ century was characterized by turbulent events in the life of human society. Tectonic shifts in the economic, political, and social structures periodically explode established order of things, cause rapid, unpredictable course of events. And perhaps the most dramatic events unfold exactly in the economic sphere. At the heart of these movements is the scientific and technical progress, and the pace is more accelerated.

Society has changed beyond recognition the appearance of new generation of tools and objects of labor, vehicles, and communications equipment. New forms of work organization and management completely changed the look and the very concept of enterprise, industry, productive and unproductive labor. Social structures and institutions underwent significant restructuring and renewal: the ratio of property, regulatory mechanisms of production and distribution of national wealth. There is a new type of labor, both individual and collective.

For nearly a century, the capitalist world at least twice made the transition to a new type of reproduction. In place of line production on the basis of rigid automation there came highly efficient, flexible production, calculated to produce a high quality product for individualized demand. One of the basic conditions for economic development was the growth of competitiveness and ensuring the leading position of domestic industry in international markets of high technology (high-tech) products.

\section{Materials and Methods}

The object of this study is innovations and their role in the development of regional economy, and the progress of the world economy. In economics, there are two types of growth: extensive and intensive. Economic growth due to an increase in the amount of resources simply by adding factors is the extensive type of economic growth. Economic growth, associated with the improvement of the quality of resources, using the achievements of scientific and technological progress, is an intensive type of growth. Accordingly, two types of growth are two groups of factors: 
1) Factors that affect the amount of resources: labor, land, capital, entrepreneurial skills. These factors do not affect the qualification of workers and their productivity, quality equipment and technology does not change;

2) Factors that affect the quality of the resource. Factors of intensive type of economic growth are: increase in the qualifications and skills of the labor force; the use of more sophisticated equipment; the most advanced technologies (primarily resource); scientific organization of labor; the most effective methods of state regulation of the economy.

The main characteristic of the quality of economic resources is their performance. Labor productivity is the number of goods and services produced per hour of working time. Labor productivity and, consequently, economic growth and its rate are influenced by the following factors (Popkova \&Tinyakova, 2013b):

- Physical capital (or equity) is stock of equipment, buildings, and structures that are used to produce goods and services. Note that physical capital is itself a result of the manufacturing process;

- Human capital is knowledge and work skills that get workers in training and workplace. Note that human capital, like physical capital, is also the result of industrial processes and also improves the company's ability to produce new products and services;

- Natural resources are factors provided by nature, such as land, rivers, and minerals;

- Technological knowledge is understanding the best ways (methods) of goods and services. Unlike technological knowledge of human capital, technological knowledge is itself the development and understanding of best practices (answer the question of how to produce), and, under the Human Capital, understanding the degree of mastery of people (labor) of these methods, transformation of knowledge into work skills.

The latter is closely related to the term "innovation". Innovation is driven in to the stage of commercial use and supply in the market as a new product. Genuine product novelty is always associated with an increase in economic benefits from its use.

It is now becoming clear that not physical, but human capital is the driving force of economic growth. Creating new ideas is the cutting edge of the economy. Science is always profitable. In the US, for $\$ 1$ invested in research, there is an average of $\$ 7$ profit. Economic advantage of the innovations is that benefits exceed the costs of the introduction of its creation. In addition, through innovation the productivity increases several times.

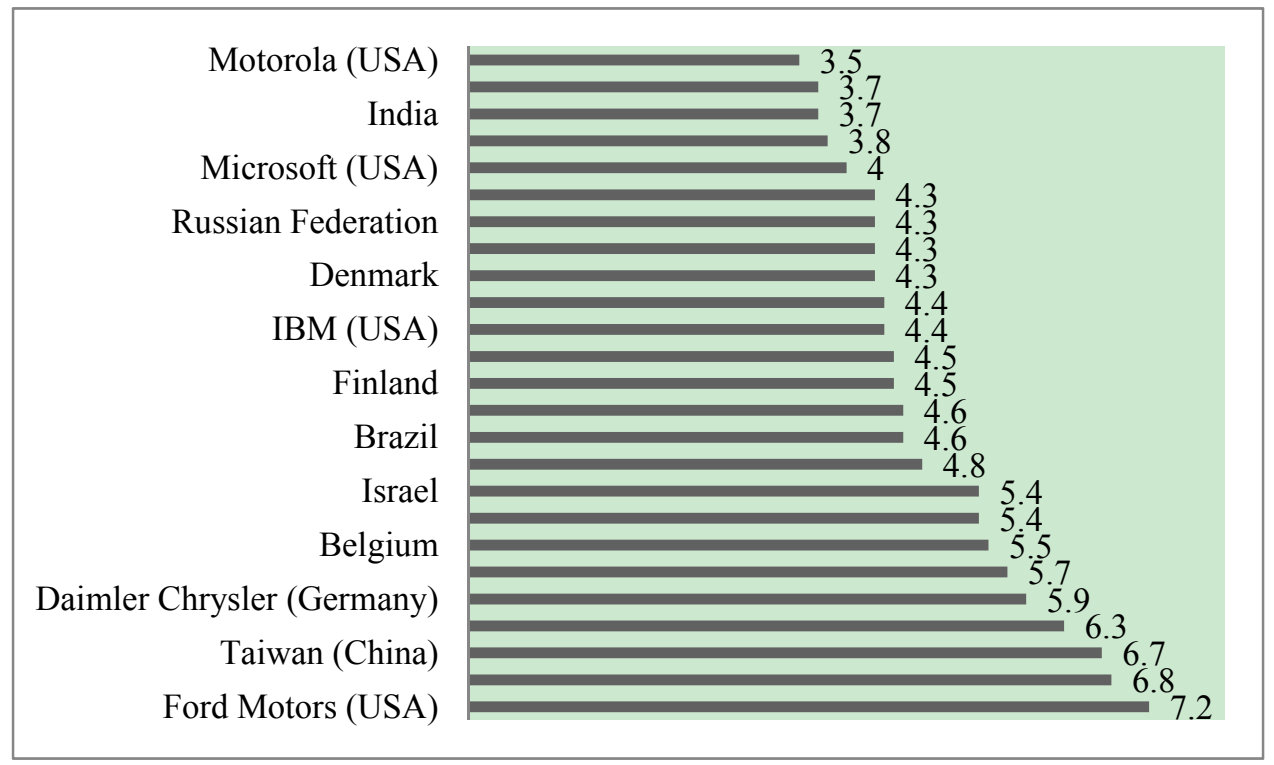

Figure 1. R\&D costs of individual countries and TNCs (2013, billion dollars) (Asheim et al., 2013)

The developed capitalist countries have gained considerable experience in the organization of the innovational processes. There is a significant gap between science and economy. One reason for this is the virtual absence of new technologies, developed by scientists and engineers for the production of new products and reduction of production costs. 
Most of our research industry cannot compete with the West. If the government does not take action, in a few years we will be completely dependent on foreign technology, created through the development and application of new technological knowledge. The question is whether we need to develop domestic production, spend financial resources on the development of the scientific base, if it is possible to import foreign technology? The answer is simple - it is necessary. Firstly, it is jobs and, as a result, decrease of the number of the unemployed. Secondly, the pre-reduction application of scientific developments in production makes scientific branch unclaimed, and consequently, uneconomical. Thirdly, new technologies make the work more efficient and allow increasing the production of goods and services.

\section{Number of researchers in R\&D sphere}

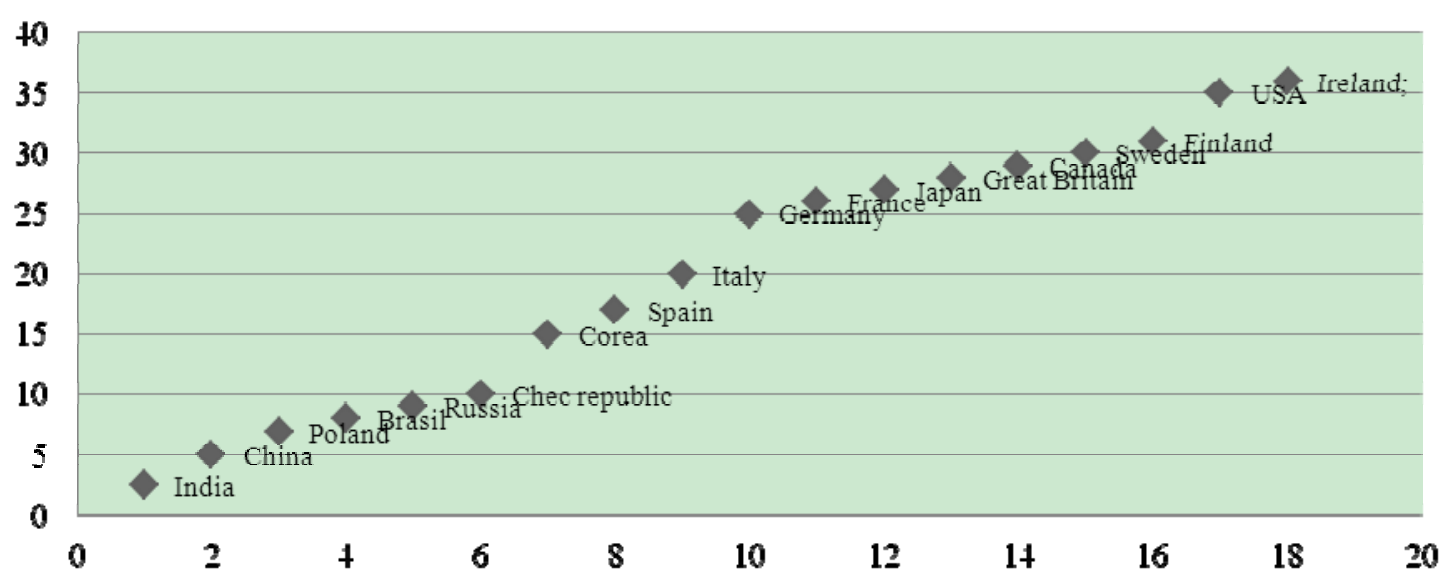

Aggregate (private and gosudartvennye) R\&D costs

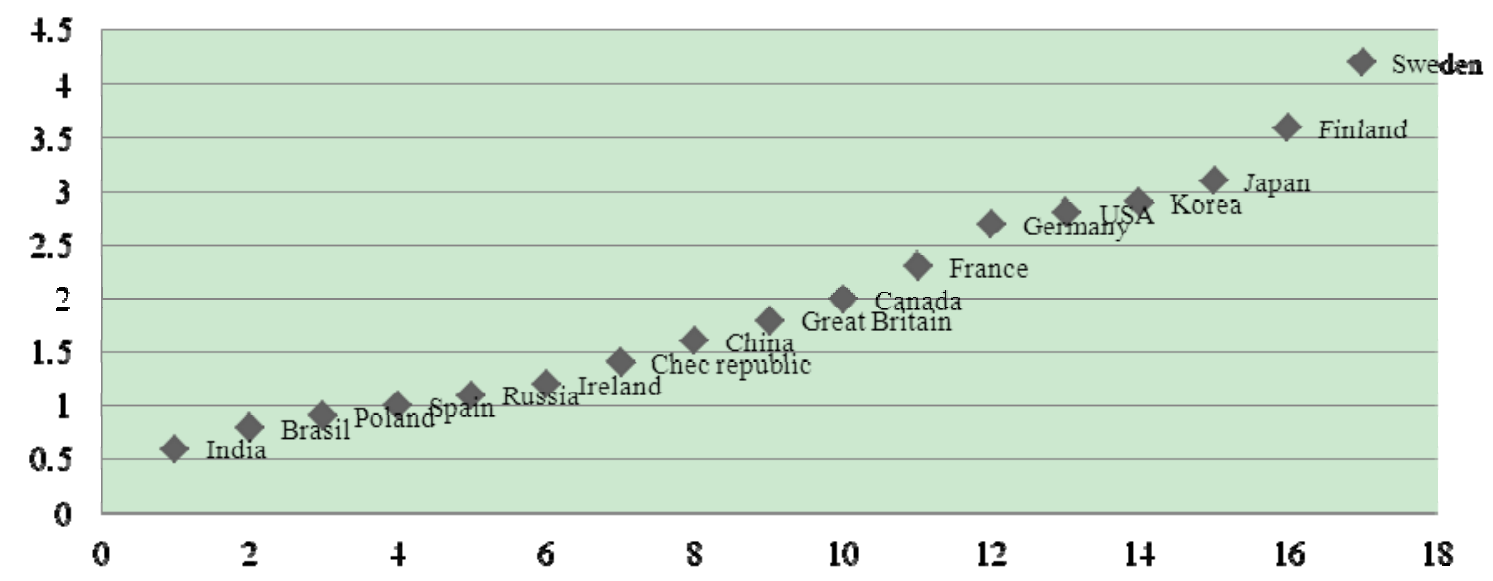

Figure 2. Number of scientists and engineers engaged to R\&D and total R\&D expenditures (different countries, 2013) (Breschi et al., 2014)

In its turn, the technological knowledge is extremely important, because it allow us solving the problem of limited resources. It is very relevant today, since minerals are non-renewable resources, and further production on such a scale, that is currently taking place, will soon lead to their total exhaustion!

Creation of highly innovative technologies and their application in industry have become a driving force of economic growth in most countries. Thus, the competition between countries is competition in the field of scientific knowledge and implementation of this knowledge in the industry (Fritsch \& Slavtchev, 2011).

In today's global economy, innovation really becomes the leading productive force, the main instrument of competition in determining economic growth, and the dynamics of the relative economic power of states. Only the most backward of the underdeveloped countries continue to hope mainly on natural resources and low cost of labor. And Russia, unfortunately, goes on the same way, despite the fact that at its disposal is still one of the 
largest in the world armies of scientists and engineers, comparable only with the "armies" of the two leading scientific and technological powers - the United States and Japan, with rapidly progressing China.

Table 1. Total government expenses in different countries (in \% of GDP) in 2013 (Hajek et al., 2013)

\begin{tabular}{lll}
\hline Country & Public health & Education \\
\hline Russia & 2.2 & 3.8 \\
Australia & 6.1 & 5.2 \\
Austria & 6.6 & 5.6 \\
Germany & 6.4 & 4.2 \\
Netherlands & 4.4 & 5 \\
Denmark & 5.8 & 8.8 \\
Sweden & 7.7 & 7.7 \\
Italy & 5.9 & 4.9 \\
Belgium & 6.6 & 8.1 \\
Bulgaria & 4.6 & 4.2 \\
Czech Republic & 6.5 & 4.4 \\
Hungary & 4.8 & 6.1 \\
Kazakhstan & 2 & 3.3 \\
Latvia & 3.5 & 6.7 \\
Lithuania & 4 & 6.3 \\
\hline
\end{tabular}

The relative size of the "bubbles" in the upper graph in Figure 2 represents the ratio of the absolute number of researchers in $R \& D$ on the ground is the absolute value of $R \& D$ costs. When it comes to the innovation process, there's a question of its main media on economic entities that perform the actual upgrade production. The peculiarity of the economic development of the capitalist economy in recent years has brought to the forefront of scientific and technical progress the small capital of individual initiators. Some researchers point to the fact that in the last decade half of all innovations in the industry in the USA were provided by small businesses, companies, and laboratories. Large corporations (often transnational activity) are by far the main carriers of the innovation process in the part where it is associated with the development of innovations, turning it into a mass product, or applied in mass production technology.

\section{Results}

Currently, innovative development is receiving increasing attention at all levels of government, municipal, and corporate management. This is no accident. According to the results of world practice, up to $30 \%$ of GDP growth (some sources say the figure is indicated in the range of $70-80 \%$ ) is provided scientific and technical development.

Economic theory identifies different types of national economic systems, depending on the criterion of their selection (agricultural, industrial, post-industrial or traditional system, administrative-command, mixed economy, etc.). Local economic system is a special type of system, since its separation occurs within the national economy. The basis of this separation are: the possibility of territorial isolation of local societies; opportunity for relative isolation and institutionalizing the goals of socio-economic development of local communities; separation of the reproduction process of the local community, based on a wide range of material needs that serve the needs of the community, but do not affect the national interest; presence and isolation of collective interest as one of the most effective tools which meet the needs of people living together (Lemag, 2013).

Isolation of the local economic system, as an independent one, and a description of its main characteristics are possible due to the presence, along with public, of private group of municipal property as a special kind of property. Municipal property, in its turn, as a special kind of property, forms the economic foundation on the basis of which a special type of economic systems - local economic systems - are formed.

Local economic system is a complex concept which is a unity of its own economic and organizational-management relations, manifested in the special nature of their reproduction. Thus, the local economic system is a set of economic relations over joint ownership, use and disposal of the means of production by the population living on separate territory, which finds its direct expression in self-management and collective appropriation of the revenue in order to ensure the functioning and development of the local community and its residents and socially important services. 
Today the activation of innovation is important as a whole and for each of its regions. The innovative character of regional development is manifested primarily in the expansion of the list of subjects of social and economic development of the region, formation of new sources and mechanisms of development, changes in the functions and tasks of territorial administration, and criteria for assessing the socio-economic efficiency of transformation and change. Regionalization of the national economy, as a manifestation of the decentralization of the economy, power and control, is a socio-economic innovation, implemented at the state level. On the "surface" of the process is the institutionalization of regional reproductive systems, partial "closure" of regional economies and the enhancing effect on the production of complex regional factors become competitive relations both horizontally and vertically.

The processes of globalization, increased competition, and dominance of innovative development - these are external factors that require modernization of the management of regional development, giving it a systematic and innovative nature. Comprehensive and systematic approaches for solving these problems form the basis for the introduction of innovative technologies in the practice of social and economic development of the region (Magro \& Wilson, 2013).

Thus, the increase of the number and variety of subjects, determined by the vector and the pace of development, is a fundamentally new factor in the life of the regions. Among the main actors are the local organs of state power, bodies of local self-government in the face of diverse social organizations and business structures. It should be noted that in most parts of the production, two-thirds of the goods and services are provided by the private sector of the economy, and there is no direct influence levers of power in the activity of economic entities.

It should be noted that the establishment of the institute of strategic planning and implementation of the methodology of strategic planning and programming in the regional management practices should not only concentrate resources on priority issues and development programs, but facilitate their effective use, integrating all the components of a common goal of social and policy regional economic development: industrial, technological, innovation, investment, social and employment policy.

Strategic development plan of the region becomes a tool that will help focus the interests and efforts of all actors of life in the region on the main goal - achieving European standards of living standards of the population. At the same time, it should increase transparency (transparency) activities of the participants of regional development, reduce the risks of economic activities and reduce its informal sector. The importance of this institution as one of the elements of the investment climate of the state and its regions is emphasized repeatedly. However, despite the worsening of attention to strategic planning and programming, many large projects, as a rule, are declarative in nature and are not connected in terms of performance or content. However, they are under-resourced, which ultimately leads to inefficient use of embedded intellectual and financial resources and unsatisfactory pace of socio-economic transformation.

\section{Discussion}

Innovative transformation of the economy can be oriented in three main stages. The first stage (preparatory) should be based on the creation of the institutional environment of the innovation economy, modernization of education and health, and launching development projects in high-tech and infrastructure sectors. It is characterized by the following features of socio-economic nature: reducing labor supply due to declining population of working age; strengthening the negative impact of restrictions imposed by the production infrastructure; increased competition in domestic markets; instability of the ruble due to lower net exports.

Main priorities of socio-economic transformation at this stage include: establishment of a regulatory framework and regulators of innovative activity of corporations; structural modernization of education, health and housing and communal services, affordable housing for employees in innovation-driven industries; reform and modernization of basic and applied science, creation of an effective innovation infrastructure; modernization of high-tech industries, creation of new technological groundwork; maintaining macroeconomic equilibrium, ensuring stable ruble exchange rate and keeping inflation at the level of $7-10 \%$ per year by the end of the period; deployment of large-scale projects to modernize transport and energy infrastructure (Popkova \& Tinyakova, 2013a).

The second stage (main) should be associated with the transition of the economy to the new technological platform, based on the promising developments in the field of information and communication, biotechnology and nanotechnology. Terms of socio-economic transformation in the second stage are characterized by the following: creation of strong research base; outstripping growth of investments in education and health and a significant increase in their efficiency; completion of large-scale projects in the energy sector; increase of the 
competitive potential of transport; extension of the competitive potential of the agricultural sector, transfer of agriculture in a sustainable mode of development with a growth rate of not less than 5-6\% per year; growing tension in the pension system, coupled with increasing demographic burden on the working population.

Main priorities of socio-economic transformation in the second stage include: creation of conditions for intensive technological renovation of corporations, based on new technologies; expansion of the position of companies in the world markets of high-tech goods and services; consolidation of specialization and competence in the high-tech markets; ensuring rational specialization of science, expansion of the advanced positions of science in the priority areas of research; creation of a network of competitive centers of higher education; integration into the world economy through the implementation of major energy and transport projects; increase of exports of transport services, information and communication services (Popkova et al., 2013).

The third stage (control) is intended to provide consolidation leading position in world economic system and innovation economy of the development mode. Its terms of socio-economic transformation must ensure the well-being of the population at the level of developed countries; deep integration into the international division of labor and production processes.

Priorities of socio-economic transformation in the framework of the innovative course should be the following: accelerated development of human capital, ensuring a leading position in terms of education and healthcare; development of cleaner production; formation of efficient economic associations in the Eurasian economic space with the participation and leadership role of access to stable demographic indicators; introduction of new forms of governance, adapted to enhance the role of global corporations and regions; creating conditions for sustainable and balanced development of the sector research and development.

Innovative modernization of the economy should be based on practical completion and implementation of a number of well-known since the end of the twentieth century domestic and foreign technologies. Actualization of the role of innovation in the process of transformation of the economy includes a wide range of conditions, instruments, and institutions:

- State support to innovation through the system of national priorities, strengthening the legal framework, and development of indicators for the future in the context of global trends;

- Dynamics of investment, directed by the state and big business, in priority sectors to support innovative transformation of the economy;

- Capacity building of competitiveness of domestic production through the mechanism of functioning of fundamental research projects;

- Implementation of promising innovative programs by consolidating the efforts of the government, science, and big business;

- Fundraising medium and large businesses to finance research, development, and innovation of new technologies;

- Intensifying efforts to form an innovative environment and conditions for the transition to business technology, ensuring high competitiveness and profitability of domestic business;

- Development of scientific forecasts of technological development in mid-term and long-term while conducting scientific expertise and innovative diagnostics of these forecasts;

- Finally, the active participation of the business community and science in training and retraining of staff capacity for timely innovative transformation of the economy.

Transition of the economy on the path of innovative development involves the implementation of a sufficiently strong research capacity and further strengthening of the institutional framework of the economy.

\section{Conclusion}

Innovative development of the region is a complex systemic problem that goes beyond the purely industrial innovation and politics, which leads to the following conclusions: socialization of the economy, investment, and labor relations have become the leading way to increase social and economic potential of the region; a necessary condition for the development of effective long-term regional development strategy is the balanced development of industrial, scientific, technical, and educational potential of the territory; strategic objective of regional investment policy should consist in creating conditions for increasing investment in human capital; formation of the regional market of innovative technologies and other infrastructure, ensuring the processes of commercialization of intellectual property, is a key social and economic issue; effectiveness of the system of 
regional governance should be evaluated, oriented, and conducted with institutional reforms that promote the growth of total regional capacity; it is essential to ensure the integrity and stability of the system and to support organizational initiatives of regional governments economic mechanisms that allow consolidating the interests and directing the activity of all subjects of economic actions in the region.

Thus, summing up the results of research, it should be noted that the study of innovation in the development of local economies is an urgent task of modern economic theory; it reflects the interest of the scientific community to a set of economic relations on joint ownership, use, and disposal of the means of production by the population, living on the isolated territory. It is important to bear in mind that this concept finds its expression in the development of self-government, including the positioning of life itself and the local community, providing its residents with socially important services. Therefore, innovation is a vector of regional economic development and a necessary condition for the progress of the world economy.

\section{References}

Asheim, B., Bugge, M., Coenen, L., \& Herstad, S. (2013). What does Evolutionary Economic Geography Bring to the Table? Reconceptualising Regional Innovation Systems. CIRCLE Working Paper no. 2013/05, Circle, Lund University.

Breschi, S., Lissoni, F., \& Tarasconi, G. (2014). Inventor Data for Research on Migration and Innovation: A Survey and a Pilot. WIPO Economics \& Statistics Series, Economic Research Working Paper No. 17, January. Retrieved from http://www.wipo.int/export/ sites/www/econ_stat/en/economics/pdf/wp17.pdf

Fritsch, M., \& Slavtchev, V. (2011). Determinants of the Efficiency of Regional Innovation Systems. Regional Studies, 45(7), 905-918. http://dx.doi.org/10.1080/00343400802251494

Hajek, P., Henriques, R., \& Hajkova, V. (2013). Visualising components of regional innovation systems using self-organized maps - Evidence from European Regions, Technological Forecasting and Social Change.

Lemag, E. (2013). 6th Forum of Moroccan Competences in North America in October in Montreal. Retrieved from http://www.lemag.ma/english/m/6th-forum-of-Moroccancompetences-in-north-America-in-OctoberinMontreal_a5000.html

Magro, E., \& Wilson, J. R. (2013). Complex innovation policy systems: Towards an evaluation mix. Research Policy, 42(9), 1647-1656. http://dx.doi.org/10.1016/j.respol.2013.06.005

Popkova, E. G., \& Tinyakova, V. I. (2013a). New Quality of Economic Growth at the Present Stage of Development of the World Economy. World Applied Sciences Journal, 5, 617-622.

Popkova, E. G., \& Tinyakova, V. I. (2013b). Drivers and Contradictions of Formation of New Quality of Economic Growth. Middle-East Journal of Scientific Research, 11, 1635-1640.

Popkova, E. G., Morkovina, S. S., Patsyuk, E. V., Panyavina, E. A., \& Popov, E. V. (2013). Marketing Strategy of Overcoming of Lag in Development of Economic Systems. World Applied Sciences Journal, 5, 591-595.

\section{Copyrights}

Copyright for this article is retained by the author(s), with first publication rights granted to the journal.

This is an open-access article distributed under the terms and conditions of the Creative Commons Attribution license (http://creativecommons.org/licenses/by/3.0/). 